\title{
Ideias e valores: a análise da ação pública a partir das interfaces entre a abordagem cognitiva e a economia das convenções
}

Paulo André Niederle' Catia Grisa ${ }^{2}$

\section{Resumo}

O foco diferenciado sobre os interesses, as ideias e as instituições delimita as três principais tradições da análise de políticas públicas. Com efeito, a unidade desses conceitos em um único corpo analítico também define o principal desafio à construção de novas abordagens que deem conta da complexidade da ação pública. O artigo contribui com essa discussão a partir de uma análise das interfaces entre a abordagem cognitiva e a economia das convenções, duas vertentes teóricas francesas que emprestam suas categorias analíticas para a compreensão dos processos de construção e institucionalização de políticas públicas. Esse diálogo permite integrar dispositivos cognitivos e valorativos em uma estrutura institucional que sustenta as redes de política pública. Finalmente, o artigo exemplifica as possibilidades derivadas dessa interface teórica a partir da sugestão de um modelo analítico para o estudo das políticas de desenvolvimento territorial no Brasil.

Palauras-chave: Ação pública. Política pública. Ideias. Valores.

\section{Introdução}

A confluência das crises financeira, política e ecológica que configura o contexto internacional, aliada à consolidaçáo das economias emergentes na

I Doutor em Ciências Sociais pelo Curso de Pós-Graduação em Desenvolvimento, Agricultura e Sociedade da Universidade Federal Rural do Rio de Janeiro (CPDA/UFRRJ) - Brasil. Professor do Programa de Pós-Graduação em Meio Ambiente e Desenvolvimento (PPGMADE) da Universidade Federal do Paraná (UFPR) - Curitiba - Brasil. E-mail: paulo.niederle@yahoo.com.br

2 Doutora em Ciências Sociais (CPDA/UFRRJ). Pesquisadora do Observatório de Políticas Públicas para a Agricultura (OPPA) da Universidade Federal Rural do Rio de Janeiro (UFRRJ) - Brasil.E-mail: catiagrisa@yahoo.com.br. 
nova geopolítica mundial, tem revitalizado justificativas de re-legitimação da ação estatal em diferentes domínios da vida social. Mesmo que a configuração precisa desse processo ainda seja objeto de intensas controvérsias, um entendimento comum tem sido produzido acerca da necessidade de conceber novos referenciais de atuação do Estado em um contexto de crise do neoliberalismo (DUMÉNIL; LEVY, 2011). Neste sentido, ao mesmo tempo em que diversos países reconstroem o aparato estatal para dar sustentaçáo a uma nova geraçáo de políticas públicas, proliferam teorias que buscam elucidar o novo contexto em que essas políticas são construídas e implementadas.

No Brasil, uma das mudanças mais significativas diz respeito às implicaçôes do processo de descentralização da formulação e execução das políticas públicas. Se na década de 1990 esse processo transcorreu como parte de uma estratégia deliberada de redução da intervenção do Estado em diferentes setores, atualmente a descentralizaçáo também pode configurar-se como um elemento potencializador da sua ação. Face à ausência do poder estatal, a ascensão da sociedade civil foi, outrora, responsável por estabelecer novos mecanismos de governança participativa, os quais, hoje em dia, mantêm-se e ampliam-se com a retomada da capacidade de atuação do Estado. Na realidade, esses mecanismos tornaram-se os principais responsáveis por viabilizar o novo papel conferido tanto ao Estado quanto à sociedade civil (DAGNINO, 2002; GOHN, 2004).

Em oposição ao modelo clássico de política pública concebida por um Estado centralizado, atuando sobre setores bem definidos e delimitados, crescem as análises que buscam acercar-se dos mecanismos da "ação pública", uma definição que acentua o conjunto das interaçôes entre os vários atores que participam da construção, implementação, monitoramento e avaliação das políticas públicas em seus mais variados níveis (MASSARDIER, 2008; LASCOUMES; LE GALÈS, 2009; HASSENTEUFEL, 2008). Essa concepção não reduz o papel do Estado, mas o define em sua interface cada vez mais evidente com outras institucionalidades. De fato, uma nova geração de políticas públicas tem demonstrado que a própria fronteira entre os três componentes da ontologia de Claus Offe (1999) - estado, mercado e sociedade civil - torna-se cada vez mais nebulosa.

Diretamente associadas à consolidação dos processos de participação e coconstrução da ação pública, as mudanças nas redes de políticas públicas 
também se associam a transformaçóes mais ou menos radicais nas instituiçóes que orientam os papéis e as condutas dos diferentes atores. Assim, além de redes mais heterogêneas, percebe-se um processo de hibridização dos valores, representaçôes e princípios normativos que regem a ação pública. Isso é resultado da constituição de fóruns e arenas no interior dos quais organizaçóes até então isoladas e sem expressividade passam a interagir de maneira dinâmica. A importância renovada das instâncias de concertação social, como os conselhos e colegiados, faz com que a disputa por recursos envolva cada vez mais lutas por legitimação e reconhecimento (HONNETH, 2003). Essas lutas colocam em evidência novas ideias, representaçóes e valores que questionam as instituições estabelecidas e passam a exigir a formação de novos compromissos para orientar a ação do estado e da sociedade civil. Ademais, em face deste contexto, abrem-se novos desafios à análise de política pública, provocando a construção de abordagens inovadoras que integrem os diferentes componentes da ação pública em um único poliedro conceitual. ${ }^{3}$

Até hoje o foco diferenciado sobre os interesses, as ideias ou as instituiçóes foi responsável por delimitar as três principais tradições de análise das políticas públicas (HALL, 1997; GRISA, 2011; FLEXOR; LEITE, 2007). Analisar as políticas a partir dos interesses consiste em identificar os atores concernidos, as lógicas da ação coletiva, os cálculos e as estratégias desenvolvidas em função dos custos e benefícios esperados da ação, assim como as consequências das antecipaçóes feitas pelos indivíduos ou pelas organizaçóes envolvidas na ação pública. Por sua vez, uma leitura centrada nas instituiçóes interroga a influência das regras, práticas e quadros mentais do passado no comportamento presente dos atores públicos e privados. Demanda um investimento histórico para identificar os recursos e os constrangimentos institucionais que regem as interaçóes no âmbito da política pública e para testar a solidez dessas instituiçóes (PALIER; SUREL, 2005). De outro modo, a "abordagem cognitiva" de análise das políticas públicas enfatiza as "ideias" compartilhadas pelos atores na construção da sua relação com o mundo (MULLER, 2008; SUREL, 2000). ${ }^{4}$ Nessa perspectiva, o foco recai sobre o conjunto de representaçóes e

3 Cabe sublinhar a importância, aludida por vários autores, de ir além dos estudos setoriais que caracterizam a maior parte da produção brasileira sobre políticas públicas, os quais expandem-se horizontalmente sem necessariamente dinamizar inovações teórico-analíticas (ROMANO, 2009; SOUZA, 2003; MELO, 1999).

4 Abordar o papel das ideias não é uma exclusividade da abordagem cognitiva. Sabatier e Schlager (2000) demonstram que dimensão cognitiva é considerada por diferentes perspectivas de análise que vão desde a escolha racional até os estudos de política pública comparada e o modelo de multiple stream. 
esquemas de interpretação que sustentam as ações públicas, ou seja, as políticas públicas são interpretadas como construídas pelas crenças comuns que definem o modo como os atores (públicos e privados) percebem os problemas sociais e concebem respostas para os mesmos.

O principal mérito da abordagem cognitiva, notadamente a perspectiva construída por Bruno Jobert e Ève Fouilleux, é o modo como pauta as disputas que envolvem a produção de "referenciais de políticas públicas", destacando os espaços onde elas acontecem (fóruns e arena), assim como a maneira de decifrar como distintos atores criam representaçóes que sustentam esses referenciais. Ademais, diferentemente de outras abordagens, esta proposta não toma as ideias como dadas. A preocupação central está nos processos de construção das ideias e como elas institucionalizam-se em políticas públicas.

Náo obstante, dentre os principais limites desta abordagem, em primeiro lugar cita-se o uso "despreocupado" que alguns autores fazem da noção de "ideias", o que leva a perda de sua capacidade heurística (FAURE; POLLET; WARIN, 1995; SUREL, 2006). Sem uma indicação precisa do que elas configuram e do modo como apreendê-las na realidade social, não raro as ideias abarcam um amplo leque de instrumentos cognitivos, englobando inclusive normas e valores. Além disso, alguns autores sugerem uma valorização excessiva das variáveis cognitivas, o que conduziria a utilizaçóes meramente retóricas que desconectam as ideias das lógicas institucionais e dos interesses que condicionam as estratégias dos atores (SUREL, 2006; FOUILLEUX, 2003; 2000). Com isso, a abordagem cognitiva, bem como outras vertentes analíticas, é continuamente desafiada a incorporar os três "is" da análise de políticas públicas - ideias, interesses e instituições (PALIER; SUREL, 2005; SUREL, 1998).

Neste artigo buscamos colaborar com essa discussão sugerindo que um quadro teórico integrando ideias, instituiçôes e valores pode ser construído a partir de uma profícua interlocução entre a abordagem cognitiva e a "economia das convençôes" (EYMARD-DUVERNAY, 2009; BOLTANSKI; THÈVENOT, 1991). Embora inicialmente focada nos aspectos cognitivos da ação econômica, a corrente convencionalista dirigiu-se para uma interpretaçâo institucionalista que destaca o papel dos "valores" na construçâo de justificativas que dão suporte às representaçôes, aos interesses e às estratégias dos atores. Como será analisado ao longo do texto, o artigo sugere que os princípios normativos sublinhados pelos teóricos das convençôes oferecem uma 
complementação aos instrumentos cognitivos. Os valores emergem como princípios que legitimam as ideias e os interesses, oferecendo um fundamento moral para os "compromissos" que fundam a ação pública em uma ordem negociada por diferentes atores. Por sua vez, a abordagem cognitiva empresta à economia das convençóes uma leitura dos dispositivos coletivos mais próximos à realidade dos atores, que náo recorrem necessariamente a valores para construir seus discursos e práticas. Na realidade, esse processo de "tradução" entre princípios cognitivos (ideias) e quadros normativos (valores) é feito por um conjunto de mediadores/porta-vozes que participam de maneira privilegiada da construção da ação pública.

O artigo está organizado em cinco seções, além desta introdução. Primeiro, retomamos o debate sociológico acerca da dualidade entre abordagens interacionistas e institucionalistas. Esta seção introduz o argumento de que tanto a abordagem cognitiva quanto a economia das convençóes constituem um complemento institucional às interpretaçóes que privilegiam o conceito de "redes de políticas públicas". De uso corrente no Brasil, a noção de redes e suas implicaçóes teóricas seráo discutidas complementarmente ao longo do artigo. Por sua vez, as duas abordagens francesas que compóem o eixo central da reflexão teórica são pouco conhecidas do público brasileiro. Em que pese o crescente apelo que ambas vêm recebendo, suas categorias analíticas não são de domínio corrente. Assim, a segunda seção é dedicada à apresentação da economia das convençóes, selecionando os conceitos que interessam ao objetivo da análise da ação pública. Do mesmo modo, a seção subsequente analisa o desenvolvimento da abordagem cognitiva. A quarta seçáo explora as interfaces entre as abordagens. Finalmente, o artigo discute as possibilidades de aplicaçáo do modelo analítico à política brasileira de desenvolvimento territorial e aponta elementos para uma agenda de pesquisa.

\section{O enraizamento normativo e cognitivo da ação pública}

Diversos autores analisam a formulaçáo e implementaçáo de políticas públicas a partir da formação de uma "rede social" que articula indivíduos e organizaçôes (RHODES, 2006; HASSENTEUFEL, 1995; MARQUES, 2000). Sem negligenciar a importância das estruturas reticulares à análise da ação pública, este artigo focaliza elementos que, de modo geral, têm recebido menor atenção nos estudos que adotam o referencial das redes, qual seja, os 
componentes cognitivos e normativos que definem uma "estrutura de sentido" para os atores da rede (MULLER; SUREL, 2004). Em outras palavras, o artigo argumenta que, mesmo tomando a rede como estrutura de análise da ação púbica, isso não exime o pesquisador de compreender o papel crucial desempenhado pelas representaçóes e pelos valores.

Amplamente sublinhada pelas abordagens institucionalistas, essa compreensão centrada nas estruturas valorativas e cognitivas da ação desaparece em muitas análises interacionistas que focalizam o funcionamento das redes de políticas públicas. Por outro lado, naquelas perspectivas onde elas geralmente são encontradas, muitas vezes essas estruturas encontram-se reificadas. Assume-se a importância inequívoca das instituições, mas nenhuma explicação é dada para o modo como elas são efetivamente incorporadas na ação social sem encapsular os atores em "explanans" que predizem suas condutas - retomando a expressão clássica de Hempel e Oppenheim (1948).

Em primeiro lugar, é imperativo reconhecer que as referências institucionais não se formam fora das redes sociais e são fundamentais para a existência e estabilização das interações. Um preceito deste raciocínio é que as próprias políticas emergem como resultado de um acordo coletivo que se processa em um ambiente social de disputas normativas. Ao mesmo tempo em que se supera a concepção naturalizada das instituiçóes, destaca-se que as dimensóes cognitivas e valorativas têm como origem a interação social. Ideias, crenças e representaçóes não se formam fora da ação situada, mas enraizadas em diferentes contextos sociais. Contudo, como sublinha a tradição dos estudos sobre path dependence (MAHONEY, 2001), as instituiçóes também carregam consigo memórias que reduzem as possibilidades dos atores. Sobre a açáo socialmente situada pesam os constrangimentos de leis, normas, regras e convençôes definidas previamente.

Dentre os autores que destacaram o componente de enraizamento da ação social, Granovetter (1985) seguramente merece destaque. Buscando afastar-se de visóes subsocializadas que atomizam os atores isolando-os do seu contexto social imediato, mas igualmente rejeitando as leituras sobressocializadas portadas por algumas análises institucionalistas, as quais priorizam disposiçôes e esquemas de percepção que encapsulam os atores por meio de regras e normas generalizadas, o fundador da nova sociologia econômica construiu uma perspectiva que torna as instituiçóes reflexos da conformaçáo de redes 
interpessoais (NEE; INGRAM, 1998). Disto resulta um conjunto de críticas ao "absolutismo socioestrutural das abordagens de redes sociais" (ZELIZER, 2003), incapazes de apreender o enraizamento cognitivo, político e cultural da ação individual (ZUKIN; DiMAGGIO, 1990).

Segundo Beckert (2007), o principal equívoco estaria em retirar o componente político-institucional da ação social, isolando unicamente o aspecto reticular das relaçóes entre os atores. Nesse caso, corre-se o risco de negligenciar as estruturas institucionais que oferecem sentido à ação, de modo que resta ausente da teoria uma explicaçáo para como as redes emergem e para as configuraçóes específicas que as diferenciam. De outro modo, a economia das convençóes sugere que a existência das redes depende crucialmente da formação de acordos valorativos. Como afirmam Eymard-Duvernay et al. (2005), a dimensão sociocognitiva associada às abordagens de redes não é suficiente para considerar operaçóes de julgamento que dependem de uma leitura política centrada em valores. Em outras palavras, a análise da ação pública não pode desconsiderar as ferramentas cognitivas e valorativas que os atores sociais desenvolvem para estabilizar as interaçóes, construir compromissos e formular políticas. Ambos, normativo e cognitivo, definem a estrutura e o desenho da rede. Caso contrário, não há nenhum princípio comum que ordene as relaçóes sociais, de modo que as mediaçóes simbólicas e valorativas são dissolvidas em um "tecido sem costura e sem fim" (VANDENBERGUE, 2006).

Desde uma leitura convencionalista, Thèvenot (2001) sustenta que a noção de rede é particularmente atraente porque permite descrever uma amplitude de entidades que geralmente são desconsideradas por outras perspectivas teóricas. Contudo, segundo o autor, "esta noção tende a negligenciar a heterogeneidade de laços para o benefício de uma imagem unificada de entidades interconectadas" (THÈVENOT, 2001, p. 408). Essa crítica tem sido incorporada pelos teóricos das redes sociais, os quais esboçam modelos alternativos para explicar a estabilizaçáo das mesmas. No modelo proposto por White (2008), o qual, inclusive, tem sido marcado por um crescente intercruzamento com as análises convencionalistas (veja FAVEREAU, BIENCOURT; EYMARD-DUVERNAY, 2002; LAZEGA; MOUNIER, 2002), são incorporadas noçôes estruturantes que "disciplinam" as açôes individuais. Assim, instituiçôes e estilos, diferenciados pelo seu nível de generalidade e formalização, oferecem significados à ação, bloqueando a livre circulação nas redes (WHITE, 2008). 
Retomando o programa de pesquisa lançado por Lazega e Favereau (2002), a questão fundamental é compreender como as lógicas institucionalizadas podem operar conectadas à heurística das redes. "Nossa perspectiva analítica não é, finalmente, tão distante do conceito de rede, mas ela destaca muito mais explicitamente o papel das ideias e das controvérsias no processo político e na ação pública" (FOULLIEUX, 2003, p. 36). Trata-se de uma perspectiva que sublinha a necessidade de os atores tomarem consciência do caráter normativo que envolve as ações públicas. Esse caráter revela-se, de modo mais ou menos explícito, em diferentes instrumentos institucionais: normas, leis, regras, regulamentos etc. Para a análise, isso exige um trabalho que envolve desde a cartografia dos atores visando saber quem participa da definição das normas da ação pública, até a identificação e reconstrução dos objetivos da política. Ademais, nesse caso atenta-se para não considerar uma política pública apenas quando suas açóes e decisóes passam a formar um todo coerente, estabilizado em normas e instrumentos. Existe um processo anterior de disputas normativas que interessa, sobretudo, aos estudos sobre formulação de políticas públicas.

\section{A perspectiva convencionalista}

Reivindicada enquanto uma corrente específica do pensamento econômico no final dos anos 1980, a economia das convençóes reúne um conjunto de estudiosos preocupados em construir uma nova interpretaçáo dos fenômenos econômicos, contrapondo-se aos preceitos utilitaristas da economia neoclássica. Em que pese diferenças conceituais ainda significativas no interior desta escola, seus autores convergiram em torno de uma agenda de pesquisa que posiciona as "convençôes" como fundamento de uma nova arquitetura teórica utilizada para analisar o comportamento dos atores e das organizaçóes (NIEDERLE, 2011). ${ }^{5}$

A origem da noção de convenção é comumente atribuída ao filósofo americano David Lewis, cujo trabalho analisou a natureza estratégica do comportamento dos indivíduos em episódios da vida cotidiana. Baseado em uma

5 Inicialmente dedicada à análise do funcionamento dos mercados e das organizações, até recentemente as formulações da economia das convenções eram menos presentes no universo de pesquisas sobre políticas públicas. Suas categorias adentram com maior expressividade nesse debate em trabalhos mais recentes (EYMARD-DUVERNAY, 2008; VERDIER, 2006; BATIFOULLIER; CADREAU, 2006). 
noção de common knowledge, Lewis (1969) construiu uma noção instrumental, completamente desprovida de caráter normativo e moral. Para ele, uma convenção é o resultado de uma "regularidade comportamental" que deriva de um saber compartilhado entre os agentes: um reflexo de cada indivíduo ao que ele espera ser o comportamento dos demais supondo seu próprio comportamento. Fundadora de uma vertente que dialoga com os modelos matemáticos da teoria dos jogos (BATIFOULIER, 2001), essa perspectiva estratégica das convençóes foi objeto de crítica em virtude de caráter radicalmente antissocial, uma vez que o "espelhamento infinito dos agentes" (cada indivíduo sabe que os demais são perfeitamente racionais) levaria a um individualismo metodológico extremo (DUPUY, 1989).

De outro modo, a vertente francesa da economia das convençóes apropriou-se do termo, mas acrescentou-lhe um caráter pragmático e interpretativo, definindo sua construçáo a partir de um contexto de comunicaçáo verbal. Nesta perspectiva, uma convençáo configura um quadro normativo cuja mobilização pressupõe engajamento moral. Trata-se de uma visão compartilhada do mundo que orienta os atores no desenvolvimento de suas práticas. Não é simplesmente uma rotina ou um hábito, haja vista que ela somente tem sentido dentro de um coletivo social. É um esquema de interpretação construído através da interação social, mas que se apresenta aos atores de forma objetivada e implícita, como um preceito de ordem moral, de modo que ela se impóe arbitrariamente aos indivíduos sem que eles questionem a possibilidade de comportamentos alternativos.

Esse entendimento é fruto de uma construção recente e ainda não totalmente estabilizada no seio dos debates convencionalistas. Em que pese à polifonia do termo em sua origem, ora descrito como um "sistema de conhecimentos compartilhado" (Salais, 1989), ora como um "sistema de representaçôes" (Eymard-Duvernay, 1989), o fato é que sua primeira acepção esteve mais próxima àquela reivindicada por Orléan (1989) e Favereau (1989), que a associa a um "dispositivo cognitivo coletivo". Somente após alguns anos de discussão emerge uma noção mais diretamente vinculada à ideia de "princípio normativo" fundado sobre julgamento de valor moral.

Segundo Batifoulier e Larquier (2001), a maior diferença entre a "pequena convenção" componente da racionalidade dos atores e a "grande convençáa" normativa é que esta comporta um imperativo de justificação. Ou seja, 
ela precisa ser publicamente legitimada com base em um "princípio superior", o que a torna, finalmente, "um mundo comum justificado". De fato, é a partir de então que a ideia de "mundo" ou "citê" se tornará central nessa acepção valorativa do termo. Náo é por acaso que, doravante, o desenvolvimento da "teoria das convençôes" vai receber um impulso fundamental da sociologia e, em especial, do trabalho seminal de Boltanski e Thèvenot (1991), cujo modelo passará a constar nos principais debates convencionalistas até o presente.

Boltanski e Thèvenot (1991) preocupam-se fundamentalmente com as operaçôes de classificação levadas a cabo pelos indivíduos em suas atividades de julgamento. Essas atividades são responsáveis por lhes propiciar um mundo social inteligível, constituindo uma condição indispensável para a coordenação de suas ações. O processo de classificação está na base da formação de acordos e da criação de princípios comuns que permitem aos atores se entenderem e conduzirem as trocas sociais. A estabilidade das relaçóes entre os atores passa a ser vista como o resultado dos "investimentos" que eles fazem para criar dispositivos convencionais que lhes "rendem" certa estabilidade frente a um espaço de múltiplas possibilidades (THÈVENOT, 1986). Por fim, a coordenação depende da construção de mecanismos que permitam às pessoas associar as práticas e os discursos a diferentes noçôes de justiça e bem comum.

Segundo os autores, comumente as interaçóes sociais transcorrem com base em equivalências estabelecidas no curso de um processo histórico de construçáo de quadros normativos. A maior parte da vida segue seu curso sem a necessidade de as pessoas e organizaçóes estabelecerem um novo acordo a cada instante que precisam interagir. Esse é basicamente o papel das instituiçóes enquanto um meio de recursos objetivos e normativos que permite coordenar a vida social. Porém, existem "momentos críticos" em que as instituiçôes estabelecidas são objeto de contestação (BOLTANSKI, 2009). . São situaçóes em que as instituiçôes são questionadas e colocadas à prova por uma realidade emergente. Momentos que catalisam a atividade reflexiva dos indivíduos, os quais são impelidos a encontrar mecanismos que permitam sair da situação transitória de incerteza e conflito.

6 De outro modo, nos "momentos práticos" em que as equivalências estão estabelecidas, as pessoas buscam se distanciar da inquietude provocada pelas críticas, minorando as diferenças e "fechando os olhos" para elementos que podem introduzir incertezas. Nestes momentos reina a "tolerância" sobre tudo aquilo que é diferente e procura-se agir de modo a retardar a disputa tanto quanto possivel (BOLTANSKI, 2009). 
Nesses momentos estabelece-se um cenário de disputas em relação à definição dos meios que serão utilizados para solucionar os problemas e, à exceçáo dos contextos de violência aberta, exige-se um amplo processo de negociação no qual os atores são obrigados a justificar publicamente seus interesses. Essas justificaçôes precisam fundar-se em princípios legítimos, caso contrário as escolhas operadas serão alvo permanente de novas críticas, até o momento em que um acordo baseado em princípios de ampla generalidade se imponha. Aqui se define a originalidade da economia das convençôes ao sustentar que as justificaçóes construídas pelos atores devem referir-se a um princípio superior comum e legítimo. Embora cada ator tenha seus próprios interesses, ele não pode extrair daí uma justificava para que todos aprovem uma determinada norma ou regra. Os interesses precisam ser justificados sob outras bases que não aquelas do próprio interesse, ou seja, fundados em princípios valorativos que remetem a "ordens de grandeza" mais amplas, associadas a distintas noçôes sobre o que é "justo".

O trabalho que se impóe, então, é identificar quais são essas ordens de grandeza. Fundamentando-se em diferentes noçóes de justiça buscadas nos escritos clássicos da filosofia política, Boltanski e Thèvenot (1991) propóem um modelo fundado em seis cités, ou mundos de justificação, cada um deles organizado sob diferentes valores: Inspiracional (criatividade); Doméstico (lealdade/confiança); Opinião (reputação); Cívico (representação); Mercado (competitividade/preço); Industrial (produtividade/eficiência). Cada um desses princípios constitui uma gramática que estrutura o comportamento dos atores e é dotado de sua própria coerência e legitimidade. Assim, rompendo com o determinismo econômico e tecnocrático que marca grande parte do trabalho de formulação e avaliaçáo de políticas públicas - pautado pelos três "es" dos manuais de administração: eficiência, eficáfia e efetividade -, estes mundos são vistos de modo não hierárquico, todos representando formas igualmente legítimas de justificação. ${ }^{7}$ Esse pluralismo sugerido pela economia das convençôes oferece uma matriz analítica para compreender políticas cuja

7 As ordens de grandeza são historicamente construidas e "a lista destes princípios não está fechada" (BOLTANSKI; THÈVENOT, 199I, p. 92). De fato, muitos dos debates ocorridos no interior da economia das convenções posteriores ao modelo sugerido em De la Justification deu-se em torno do reconhecimento de novas ordens de grandeza. Um verdadeiro movimento foi iniciado à "procura da sétima cité", retomando os termos de Latour (1995) quando este discute a pertinência de a ecologia constituir uma ordem própria em vista da impossibilidade de ela ser dissolvida dentro daquelas seis até então apresentadas. 
legitimidade recai sobre uma complexa conjunção de valores, abarcando, por exemplo, desde a geração de emprego e renda, até a conservação do patrimônio natural e cultural.

Se, por um lado, o modelo sugere evitar a hierarquização de modo apriorístico das ordens valorativas (cités), por outro, é preciso reconhecer que as formas de justificação que elas engendram convivem em estado de tensão permanente, umas resistindo a invasão das outras e tentando impor seu modo de coordenação. As tensóes opondo os projetos pessoais e a necessidade de seguir as regras estabelecidas por um coletivo (associação, cooperativa) expressam dificuldades de integração dos mundos doméstico e cívico. Por sua vez, o conflito entre os mundos doméstico e industrial é amplamente pronunciado quando da emergência de uma política de inovação tecnológica que incrementa eficiência aos processos produtivos mas coloca em risco a reprodução de populaçôes tradicionais e de seus costumes e práticas. Em cada política pública existe uma composição específica de valores legítimos que definem seu modo de coordenação, no interior do qual alguns impóem-se perante os demais. Assim, a hierarquização dos valores não é uma decorrência da teoria (rompendo, por exemplo, com o economicismo utilitarista), mas o resultado do modo como os próprios atores sociais coordenam suas açóes.

A partir dessa construçáo fundada em princípios valorativos, a economia das convençóes propóe uma abordagem institucional que permite examinar a "substância dos laços sociais que unem os atores em redes" (BIGGART; BEAMISH, 2003). Trata-se de uma perspectiva que exige a análise de um movimento de generalização em direção a estruturas ideais que integrem os elementos valorativos que dáo sentido à açáo. Para que a ação pública constitua-se de modo perene, é preciso que os atores entrem em acordo sobre um conjunto de normas que definem como os instrumentos serão desenhados. Normas e regras são necessárias porque elas definem uma orientação cognitiva e moral.

Contudo, enquanto para os interacionistas as normas e regras são o produto (a posteriori) da ação situada, de modo que a coordenação se estabelece no nível mais elementar da associaçáo entre atores no interior da rede social, a economia das convençóes acrescenta que as regras precisam ser interpretadas, de onde advém a necessidade de ascender às estruturas institucionais mais amplas que conformam um quadro valorativo onde os atores buscam ferramentas para interpretá-las (POSTEL; SOBEL, 2006). A construção do modelo de 
"mundos de justificação" pressupóe esse movimento de montée en généralité que visa reconhecer ordens de grandeza comuns a partir das quais pode-se estabelecer parâmetros mínimos de coordenação. Neste caso, a própria formação de uma rede, fórum ou arena de política pública, depende da possibilidade de os atores entrarem em acordo sobre o que os une (e construir sistemas de classificação).

Nesses termos a questáo fundamental passa a ser: como construir uma abordagem institucional sem ser excessivamente globalizante perdendo de vista os atores sociais? Como ascender às alturas ideais dos "mundos" sem desconsiderar os mecanismos cognitivos menos diretamente constrangidos por justificaçóes generalizantes? A resposta a essas questóes desenvolve-se a partir do reconhecimento de um segundo tipo de pluralismo relacionado aos múltiplos níveis convencionais existentes entre as formas generalizantes de coordenação fundadas em valores morais (os mundos) e aqueles mecanismos mais localizados e personalizados (os dispositivos cognitivos). Resultado de um aprofundamento analítico mais recente no interior da abordagem convencionalista, esse pluralismo "vertical" (os diferentes mundos sendo o "horizontal") acena à necessidade de reconhecer diferentes graus de generalidade ou publicidade das convençóes. É uma tentativa de diferenciar a noção genérica de convenção, enquanto mundo comum justificado, de formatos locais de coordenação (THËVENOT, 2001).

Aqui busca-se reconhecer que, às formas de coordenaçáo repousando sobre princípios gerais de ação, é necessário adicionar formas de coordenação mais locais, que mobilizam os atores sociais e encontram-se mais próximas das pessoas (EYMARD-DUVERNAY, 2006). A questáo é precisamente articular os dois níveis da coordenação, descendo até os dispositivos de coordenação particulares a cada contexto ou grupo social, buscando acercar-se dos aspectos mais tácitos ou informais, e reascender a um plano macro que permita construir uma abordagem unificada dos dispositivos de coordenação da ação pública. Este movimento de circulação entre diferentes níveis de governança traz para o primeiro plano da análise uma discussão sobre o papel dos "intermediários" ou "mediadores" (BOLTANSKI; CHIAPELO, 1999). São atores que se encontram de modo cada vez mais evidente em distintos espaços públicos e os responsáveis pelo processo de "traduçáo" que deve existir entre os dispositivos cognitivos e valorativos. Por um lado, eles trabalham para definir 
uma legitimidade moral às ideias e representaçóes construídas pelos atores; por outro, eles conectam os dispositivos valorativos ao discurso e às práticas efetivamente pronunciados pelas pessoas, as quais não recorrem necessariamente a princípios morais para justificar condutas e interesses.

\section{A abordagem cognitiva de análise da ação pública}

Diferentemente da economia das convençóes, mas no mesmo período histórico, a abordagem cognitiva nasce diretamente associada ao debate sobre o papel das ideias na construção das políticas públicas, as quais, por sua vez, são compreendidas como o resultado de interaçóes sociais que dão lugar à produçấo de representaçóes comuns. Como afirma Surel (2000), as políticas públicas são analisadas como um constructo derivado das crenças compartilhadas por um conjunto de atores públicos e privados, as quais definem a maneira como estes interpretam e concebem respostas para os problemas públicos.

Atualmente, a abordagem cognitiva vem sendo discutida com maior ênfase em países como França, Estados Unidos e Inglaterra, mas a partir de noçóes distintas. Tal qual a economia das convenções, longe de confluir para uma perspectiva unificada, a abordagem cognitiva comporta diferentes interpretaçôes. A unidade teórica provém da centralidade conferida às ideias, mas, para além disso, o que se nota é uma proliferação de noçôes e categorias analíticas que incluem distintas terminologias: referencial, fórum, arena, paradigma, sistema de crenças, narrativas, discursos etc.

No seio deste conjunto heterodoxo, a perspectiva que enfatiza a noção de "referencial" ganhou certo destaque. Desenvolvida por Jobert e Muller (1987), ela define as políticas públicas como processos por meio dos quais são elaboradas representaçóes coletivas para compreender e agir sobre o real. Em outras palavras, a elaboração de uma política pública envolve a construção de uma representaçáo da realidade sobre a qual se intervém e, por meio desta imagem denominada "referencial de política pública", os atores interpretam os problemas, confrontam possíveis soluçóes e definem suas açóes. ${ }^{8}$

8 Para Jobert e Muller (1987), o referencial de uma política pública pode decompor-se em dois elementos: referencial global e referencial setorial. O referencial global refere-se a um quadro geral de interpretação do mundo, superando os limites de um setor, de um domínio ou de uma política. Trata-se da "[...] representação 
Jobert (1992) concebe os referenciais a partir de três dimensóes: cogniti$v a$ - fornece os elementos de interpretação causal dos problemas; normativa - define os valores que são necessários respeitar para o tratamento do problema; e instrumental - define os princípios de ação. Por sua vez, Muller (2008) define a construção de um referencial a partir da articulação de quatro níveis integrados de percepção do mundo: a) os valores, vistos como representaçôes mais amplas e fundamentais sobre o que é bom ou mau; b) as normas estabelecidas entre o real observado e o real desejado, definindo os princípios de açáo mais que os valores; c) os algoritmos concernentes às relaçóes causais que exprimem uma teoria da ação e; d) as imagens, que são elementos cognitivos que fazem sentido imediatamente e representam simplificadamente os vetores dos valores, normas e algoritmos. Para ambos os autores, nota-se que o papel conferido aos valores transparece em um nível superior de composição dos referenciais.

Os referenciais construídos pelos atores em um jogo de dominação e disputas tomam a forma de "verdades", mais difíceis de serem contestadas na medida em que se revelam eficazes para dar sentido ao mundo vivido pelos agentes (MULLER, 2005). Essas matrizes cognitivas e valorativas tendem a autonomizar-se em relação ao seu processo de construçáo e a impor-se aos atores como modelos dominantes de interpretação do mundo. Os referencias são, simultaneamente, constrangimentos estruturais e o resultado do trabalho sobre os sentidos efetuados pelos atores.

Em estreita relaçáo com a perspectiva dos referenciais, mais recentemente outra vertente vem discutindo o papel das ideias a partir das noçóes de "fórum" e "arena" de políticas públicas. Inicialmente proposta pelo próprio Jobert $(1995 ; 1994 ; 1992)$ em resposta às críticas dirigidas ao livro L'état en

que uma sociedade faz da sua relação com o mundo em um momento dado" (MULLER, 2008, p. 65) e é em torno desta representação geral que serão hierarquizadas as diferentes representações setoriais. O referencial setorial diz respeito às representações de um setor, entendido, segundo Muller (2005), como uma estrutura vertical de papéis sociais que congrega regras de funcionamento, elabora normas e valores especificos e delimita suas fronteiras. De modo simplificado, um setor é formado por um conjunto de problemas associados de maneira mais ou menos institucionalizadas a certas populações. Ambos, referencial setorial e referencial global, encontram-se articulados ou tensionados para que assim seja. Para os autores desta perspectiva, as mudanças ou a construção de uma nova política pública são resultados de alterações no referencial setorial no sentido de ajustá-lo ao referencial global. Realizando as operações de confluência global/setorial e mediando as relações de poder encontram-se mediadores que conectam dois espaços de ação e de produção de sentidos para construir o referencial da política pública (MULLER, 2005). 
action (obra anterior escrita com Pierre Muller), e, mais recentemente, capitaneada por Éve Fouilleux $(2011 ; 2003 ; 2000)$, essa vertente passa a integrar um conjunto de novos desenvolvimentos analíticos no interior da abordagem cognitiva.

Neste caso, as pesquisas voltam-se à compreensão das modalidades de produção das ideias e sua emergência no debate como "receitas de ação pública" (FOUILLEUX, 2000). "As ideias serão entendidas como designando um conjunto de representaçóes, grades de análise e esquemas de interpretação diversos que fazem sentido através da sua encarnação em comunidades de atores específicos" (FOUILLEUX, 2000, p. 278). Ao centrar-se nas ideias "encarnadas" em comunidades de atores", essa perspectiva busca uma articulação entre ideias, instituições e interesses, dimensões até então analisadas separadamente e pouco integradas à abordagem cognitiva. Compreende-se que os interesses são construçôes sociais que mobilizam crenças e representaçóes acerca do mundo, de modo que para defendê-los é necessário criar representaçóes sobre o objeto, executar operaçóes intelectuais de decodificaçáo e recodificação da realidade, acionando ideias e sistemas de cognição (JOBERT, 2004; FOUILLEUX, 2003). Por sua vez, as instituiçóes são apreendidas como quadros normativos que enquadram as interaçóes sociais. Isso inclui desde o arranjo formal que define o sistema político (constituição, leis, ministérios) até os próprios instrumentos da política pública (normas, manuais, formas de conduta).

No que tange ao conceito que conforma a pedra fundamental dessa articulação analítica, fórum é definido como um espaço mais ou menos institucionalizado e especializado, regidos por regras e dinâmicas específicas, no qual um grupo de atores debate diferentes visóes de mundo (FOUILLEUX, 2009). Existem duas categorias de fórum: fórum de produção de ideias e fórum de comunidades de política pública.

O primeiro são espaços onde são conformadas diferentes representaçóes sobre as políticas, as quais variam segundo interesses, identidades, relaçóes

9 A noção de comunidade de política pública é compreendida aqui de modo distinto daquele como alguns autores a empregam na abordagem de redes de política pública. Para esses atores, a comunidade caracteriza-se por um número limitado de participantes que partilham a mesma ideologia, valores e preferências. Ademais, essa perspectiva pressupõe uma interação frequente e intensa entre todos os membros da comunidade, os quais possuem recursos similares, ocasionando um equilibrio de forças (ROMANO, 2009; MULLER, 2007). De outro modo, para Fouilleux (2003), a noção de fórum sugere uma composição mais hibrida em que os interesses, as representações e os valores não são necessariamente similares. 
de poder e institucionalidades específicos. Além das ideias manipuladas e produzidas sobre uma mesma política diferirem nesses espaços, também são distintos os critérios de aceitabilidade e coerência dos discursos, bem como a evolução das controvérsias e disputas. Para ilustrar, cita-se o trabalho de Jobert (1994) que identificou a influência de dois fóruns de produção de ideias (o fórum científico e o fórum da comunicação política) na expansão do neoliberalismo na Europa. Já Fouilleux (2003), estudando as reformas da Política Agrícola Comum no contexto europeu, evidenciou a influência de quatro fóruns de produção de ideias: fórum científico, fórum da comunicação política, fórum dos profissionais agrícolas e fórum ambiental. Por sua vez, Grisa (2012) observou a influência de cinco fóruns de produção de ideias na construção de um conjunto de políticas para a agricultura familiar no Brasil: fórum da comunicação política, fórum científico, fórum da segurança alimentar e nutricional, fórum da agricultura familiar e fórum agroecológico. Cada fórum de produção de ideias agrega atores que atuam mais ou menos no mesmo campo de atividades, como, por exemplo, no governo ou em organizaçóes de agricultores, ou ainda em centros de pesquisa e ensino.

Os fóruns de produção de ideias seguem dinâmicas diferenciadas e apresentam referenciais centrais distintos. "Referencial central" diz respeito ao conjunto de ideias e representaçóes específicas que são dominantes em um dado fórum de produção de ideias, o qual define os objetivos, enquadra os debates, assegura uma relativa estabilidade nas trocas e permite aos atores situarem-se e identificarem-se (FOUILLEUX, 2000). Todavia, a construção de um referencial central não impede a existência de vozes dissidentes que o recusam e o desafiam, de modo que uma dinâmica de crítica e contestação pode levar à desestabilização das ideias institucionalizadas. ${ }^{10}$ Esses "momentos críticos" podem vir à tona em uma eleição governamental, na escolha de um novo representante da categoria sindical ou em uma revoluçáo paradigmática no fórum científico. Cabe notar, contudo, que a controvérsia presente nos fóruns de produçáo de ideias somente ameaça a estabilidade do referencial central

10 Fouilleux (2000) alude que a dinâmica de construção do referencial central nos fóruns de produção de ideias é do tipo "traducional", conforme propõe a sociologia de Michel Callon. Neste processo, há a designação de um grupo de atores como porta-vozes legítimos do fórum e a imposição de suas ideias como referencial dominante. Os porta-vozes são legitimados para emitirem suas próprias visões de mundo ao exterior como se fossem aquelas do próprio fórum. 
quando os atores dissidentes, antes marginais, adquirirem condições que lhes permitam colocar em questáo o referencial dominante (alianças no interior e exterior do fórum de produção de ideias, reconhecimento e apoio da opiniáo pública, relação com o governo, apoio de organizaçóes da sociedade civil etc.).

Por sua vez, o fórum de comunidades de política pública é espaço de encontro e discussão dos porta-vozes dos diferentes fóruns de produção de ideias, onde há a reutilização, seleção e institucionalização das ideias produzidas por estes, convertendo-as em instrumentos de política pública. Enquanto nos fóruns de produção de ideias os atores são relativamente homogêneos em termos de campo de atividade em que atuam e as representaçóes convergem com maior facilidade, no fórum de comunidades de política pública a heterogeneidade torna-se a marca mais expressiva (políticos, intelectuais, profissionais, administradores públicos, cientistas etc.), tornando inteligível a heterogeneidade das representaçóes em torno de uma política pública (FOUILLEUX, 2000). Assim, existe um processo de circulação de ideias dos diferentes fóruns de produção de ideias para o fórum de comunidades de politica pública, constituindo etapas sucessivas em presença de atores distintos.

Uma vez institucionalizadas em políticas, as ideias passam a repercutir nos fóruns de produção de ideias, influenciando e reorientando o debate. Desse modo, os instrumentos da política pública são dispositivos sociotécnicos que organizam as relaçôes sociais entre o poder público e os beneficiários da política em função das representaçóes e significados que portam, influenciando as ideias e interesses (LASCOUMES; LE GALÈS, 2004). Esses instrumentos não são neutros. Eles portam valores alimentados por interpretaçóes do social e concepçóes precisas do problema visado, enquadrando e nutrindo as interaçôes sociais. Trata-se do efeito feedback das políticas públicas (PIERSON, 2006).

A influência de cada fórum de produção de ideias na construção de uma política pública depende de sua dinâmica de funcionamento e dos recursos que ele possui para impor suas ideias. Por exemplo, a ligaçáo entre o fórum da comunicação política e o fórum de comunidades de política pública é fortemente institucionalizada. Uma vez que um partido ou coalizão domine o processo de tradução no fórum da comunicação política (eleição), ele compóe automaticamente o fórum de comunidades de política pública e passa a ser responsável (juntamente com os gestores e técnicos administrativos) por 
construir um "compromisso" entre os atores que participam deste espaço. Assim, as ideias contidas nos programas eleitorais são diretamente importadas para o fórum de comunidades de política pública (não dependem de trocas políticas como nos demais fóruns)."

A atividade principal do fórum de comunidades de política pública é a produção de suas próprias instituições, especialmente a política pública (FOUILLEUX, 2000). A produção de uma política pública envolve a construção de um referencial que é a materialização das ideias (e valores) em instrumentos de política. Este referencial também pode ser considerado um "referencial central", como aludido acima, todavia, neste caso, trata-se de um referencial "híbrido", cujos sistemas de representação que o constituem são oriundos de diferentes fóruns de produção de ideias. Nas palavras de Fouilleux (2000, p. 289), "o referencial central da política pública é definido como resultante de uma controvérsia que empresta e reutiliza as ideias oriundas dos debates travados por referenciais de natureza diferentes". Longe de uma coerência perfeita, o referencial permite explicar a heterogeneidade e as contradiçóes internas que serão encontradas em uma política pública.

No fórum de comunidades de política pública, a dinâmica segue a procura por um modo de definiçáo da realidade social no qual seja possível obter um "compromisso" entre as partes envolvidas para a elaboração da política pública. Enquanto os atores aderirem ao compromisso formado, a política pública segue seu curso "normal" (Surel,1995), não sendo questionada ou alterada em grandes proporçôes. Todavia, quando esse compromisso é ameaçado, o fórum muda de configuração e ingressa em uma fase instável de renegociação do compromisso institucionalizado (momento crítico) onde o debate torna-se visível ao grande público, ainda que não seja facilmente inteligível (FOUILLEUX, 2000).

11 Todavia, isso não significa a institucionalização direta destas ideias, o que depende dos acordos estabelecidos com os porta-vozes dos demais fóruns de produção de ideias em busca da construção de um compromisso entre interesses e concepções heterogêneas. A interface entre o fórum da agricultura familiar e o fórum de comunidades de política pública é permeada por trocas políticas e negociações tensas entre a manutenção da ordem social, reconhecimento de porta-voz e a elaboração de políticas públicas, sobretudo distributivas e redistributivas. Já a ligação do fórum de comunidades de política pública com o fórum científico, outro exemplo, envolve demandas de análises cientificas concernentes à relação entre Estado, sociedade e políticas públicas, em troca de retribuições financeiras e simbólicas aos experts. 
A vida de um fórum de comunidades de política pública é ritmada pela alternância entre fases de estabilidade e conjunturas críticas, constituindo dois tipos de dinâmicas: a) uma configuração fórum quando a controvérsia é colocada em latência e há a produção rotineira da política pública, com mudanças marginais e incrementais que não questionam a economia geral do compromisso e; b) uma configuração arena quando o compromisso é colocado em xeque e as controvérsias são expostas (conjuntura crítica do fórum). Nesse caso, a instabilidade institucional é mais suscetível de traduzir-se em mudanças de magnitudes maiores ou na criaçáo de uma nova política pública. A estabilidade é retomada somente quando há a renovação ou a criação de um novo compromisso.

A crise no fórum de comunidades de política pública pode ter origem seja na tentativa de um ator aumentar seu poder e/ou sua legitimidade modificando o compromisso (estratégia ofensiva); seja na vontade de um ator modificar o compromisso para conservar sua legitimidade (estratégia defensiva); ou ainda com a chegada de um ator reivindicando o direito de participar da elaboraçáo da política pública (outro caso ofensivo). Se o compromisso entre os atores não pode ser renovado em decorrência da crise, as trocas políticas e a legitimidade dos atores detentores de poder ficam ameaçadas. A crise termina quando se estabelece uma nova situação de estabilidade satisfatória do ponto de vista da repartição dos recursos e da legitimidade de cada um dos atores em função das relações de força existentes.

\section{Integrando ideias e valores à análise da ação pública}

Como visto acima, o programa fundador da teoria convencionalista formou-se em torno de uma noção de convenção concebida como "dispositivo cognitivo coletivo". Contudo, o desdobramento das discussôes incitou um afastamento dessa compreensão - que imputava uma referência ao individualismo metodológico - para afirmar o papel determinante dos valores na configuração de racionalidades cada vez mais interpretativas do que cognitivas (CAILLÉ, 2006). ${ }^{12}$ Esse deslocamento do cognitivo em direção ao valorativo

12 É imprescindivel referir aqui o vínculo estreito que essa mudança de enfoque da escola convencionalista - de um individualismo metodológico para uma compreensão da ação socialmente situada - possui com os desdobramentos teóricos do interacionismo simbólico e da etnometodologia, os quais estiveram na base da perspectiva pragmatista assumida pela sociologia das convenções (JOAS, 1993). A defesa de uma racionalidade 
foi analisado por Boyer (2006), para quem a priorização da esfera dos julgamentos de valor torna o ator social da economia das convençóes um sujeito moral que busca nos valores a legitimação dos mecanismos de coordenação (normas, regras, leis e instrumentos). De fato, parte considerável da contribuição aportada à economia das convençóes pelo Grupo de Sociologia Política e Moral (GSPM-EHESS) insere-se neste esforço de compreender como os valores medeiam e justificam representaçóes cognitivas.

No entanto, esse movimento de generalização em direção aos valores pode tornar ininteligíveis as formas de coordenação mais próximas aos atores. Como afirmam Bessy e Favereau (2003, p. 131), "há uma preocupação de ascensão em generalidade e publicidade na argumentação ao nível das " $c i$ tés" que não se reencontrará necessariamente ao nível das convençôes que permitirão administrar um problema local". Em outras palavras, frequentemente a priorizaçáo dos componentes valorativos e interpretativos desvia a preocupação da economia convencionalista dos dispositivos cognitivos (ideias e representaçóes) que estruturam sentidos mais próximos à realidade dos indivíduos implicados na ação pública.

De outro modo, a abordagem cognitiva procura integrar as ideias a um conjunto de princípios gerais que constituem uma estrutura de referência para a ação pública. Ademais, a análise da dinâmica dos fóruns também busca desvelar a interconexão entre ideias e interesses, definindo uma dinâmica de conflito social diferente daquela que focaliza a economia das convençôes. Aqui é necessário um parêntese para tratar especificamente da questão dos interesses e do conflito concernente à ação pública.

Para muitos críticos, a concepção de sujeito moral defendida pela economia das convençóes retrata sua incapacidade de analisar as relaçôes de força e os diferenciais de poder entre os agentes, o que, enfim, expressaria uma espécie de preferência pelo consenso vis-à-vis a lógica do conflito (AMABLE; PALOMBARINI, 2005; LIVIAN; HERREROS, 1994; RAMAUX, 1996; PERIN, 2005). De fato, o tipo de conflito abordado pela economia das convençôes náo diz respeito aos interesses dos atores e grupos sociais em luta dentro de um determinado fórum ou arena. Trata-se de um tipo específico de

situada (THÈVENOT, 1989) e interpretativa (BATIFOULIER; LARQUIER, 200I) é particularmente subsidiária dos estudos de Herbert Blumer acerca da racionalidade contextual do ator social. 
disputa que diz respeito às formas de justificação utilizadas pelos atores para legitimar suas açóes. Um conflito que se processa em um ambiente institucional que não é de guerra e, portanto, que deve ser negociado. Em última análise, um conflito que se desenvolve com vistas à produção de compromissos, ou seja, de um tipo específico de acordo valorativo. ${ }^{13}$

Isso não significa negligenciar a existência de outras formas de conflito, mas reconhecer a possibilidade de analisar uma categoria específica. Para Bessis (2007, p. 3), essa compreensão "não exclui a busca do agente por seu interesse pessoal, mas lhe acrescenta um senso de justiça". De acordo com o autor, não se trata de subsituir o interesse pela procura altruísta do bem comum, mas integrá-lo dentro de uma explicação mais abrangente que reconhece outras lógicas de ação. A inovação radical da proposta convencionalista é o imperativo de interpretação e justificação dos interesses. Ainda que os atores persigam seus interesses, a constituição de um acordo obriga-os a justificar suas práticas com base em princípios valorativos. "No lugar de seres transparentes ou de seres reduzidos aos interesses, dos quais eles eram julgados ser a expressão transfigurada, os valores morais voltam diante da cena sociológica como motivos das açóes desenvolvidas pelas pessoas" (BOLTANSKI, 2002, p. 282).

Compreender os conflitos entre diferentes princípios normativos não exclui, todavia, a tarefa de interpretar as disputas que se processam em outros níveis, como aquele das ideias e representaçóes. Como sugere a Fig. 01, as interfaces analíticas entre as abordagens convencionalista e cognitiva possibilitam uma complementaridade entre níveis de coordenaçáo. Esta permite uma aproximação às lógicas de ação mais próximas aos atores, acercando-se das representaçóes sociais que estes desenvolvem para dar sentido aos seus discursos e práticas. Aquela revela que as representaçôes socialmente situadas necessitam de uma estrutura mais ampla que lhes dê sentido, os valores. Com isso a teoria das convençóes confere um suporte normativo que, apesar de reconhecido

13 É preciso aludir que, aqui, o foco direciona-se aos "regimes de justificação", os quais requerem um espaço público de contestação e crítica. No entanto, existem "mundos de ação" (CORCUFF, 200I) onde a lógica é distinta, podendo constituírem-se estados de amor (regimes de violência ou agápe) ou formas de coordenação baseados em "conveniências pessoais" ou "utilização convencional" (THÈVENOT, 200I). Nestes casos, não existe uma dinâmica de crítica que dê acesso aos valores morais que as pessoas reclamam para justificar suas ações com base em princípios comuns. Particularmente em regimes de extrema violência, onde a crítica é praticamente impossivel, as justificações desaparecem, assim como a dinâmica da construção de "compromissos" (BOLTANSKI, 2002). 
pelos autores da abordagem cognitiva, raramente é incorporado de maneira efetiva à análise. Por fim, interligando os dois níveis existe um conjunto de mediadores responsáveis pelos processos de tradução. Esses mediadores desempenham um papel fundamental na definição das normas, regras, leis e instrumentos, associando-os às estruturas cognitivas e valorativas.

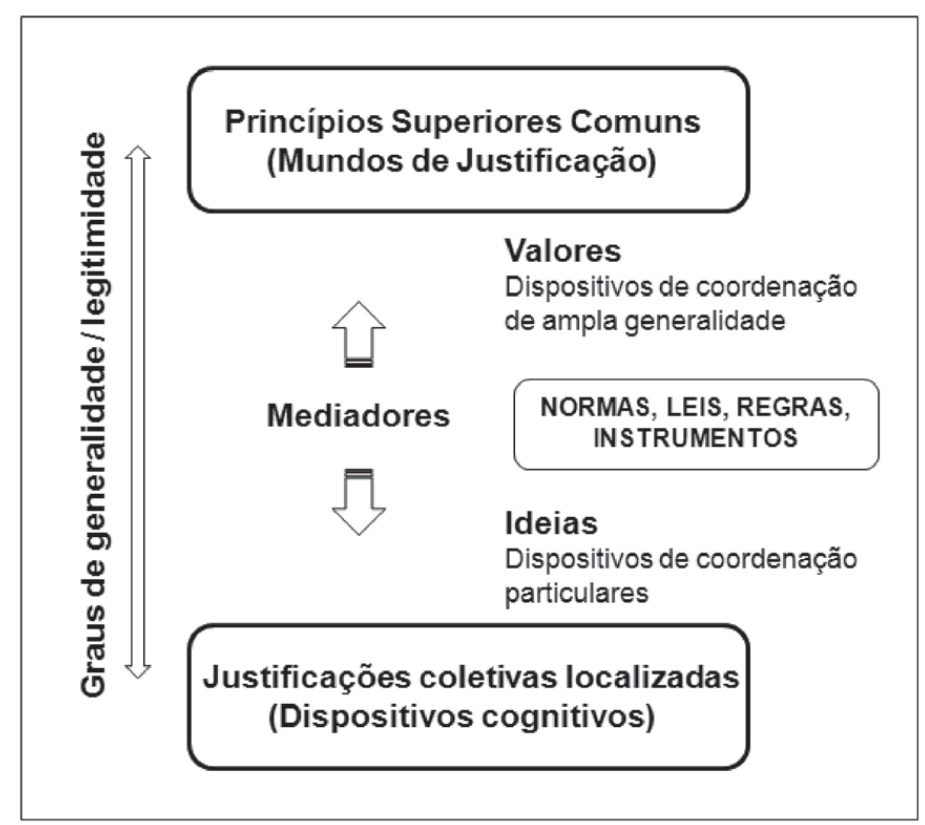

Figura I - Níveis de coordenação da ação pública

Fonte: Elaborada pelos autores.

A formação desse corpo analítico incorre na necessidade de ajustes conceituais de categorias que parecem caminhar umas de encontro às outras. A primeira referência neste sentido diz respeito ao modo como a proposta de Fouilleux (2003) concebe as ideias como "representaçóes encarnadas" nos atores, ao passo que a economia das convençôes assume que os indivíduos movem-se entre diferentes valores. No primeiro caso, as ideias pertencem aos atores de modo que há uma identidade mais ou menos estável entre as representaçóes e os interesses. No segundo, assume-se que o mesmo ator, em diferentes circunstâncias, pode mobilizar valores distintos para justificar o mesmo interesse. Assim, para a economia das convençôes, é observando o encadeamento de sequências de açáo que se pode observar a passagem de um regime de justificação para outro (DODIER, 1991). 
A nosso ver, contudo, alguns constrangimentos devem pesar sobre essa movimentação dos atores. $\mathrm{O}$ mesmo ator não pode circular ininterruptamente entre os mais diferentes princípios de justificação sem que isso lhe acarrete algum custo, fragilizando sua posiçâo e legitimidade perante os demais - sobretudo se considerarmos a presença simultânea do mesmo ator em diferentes fóruns de produção de políticas, inclusive cruzando as fronteiras entre estado e sociedade civil. Aqui a noção de "fórum", que ambas as abordagens compartilham com a sociologia do ator-rede de Callon, configura uma categoria fundamental porque também define as rotas pelas quais os atores podem se movimentar. Cada fórum é composto por uma institucionalidade própria que estabelece condiçóes mínimas para a circulação dos atores (FOUILLEUX, 2009).

A noção de fórum delimita com mais clareza a posição dos atores na "rede de política pública". Os diferentes princípios cognitivos e normativos que regem a formaçáo dos fóruns podem ser considerados a substância que define o formato das redes, explicando a formação de comunidades (cliques) no interior desta, assim como a presença de "buracos estruturais" que isolam certos atores (BURT, 1992). O fórum é a ferramenta analítica que permite estabilizar uma determinada conformação da rede para que o pesquisador possa observá-la. Eles definem uma espécie de entrave à livre circulação dos atores, reclamando certo engajamento, mesmo que parcial e temporário.

Entretanto, a abordagem cognitiva ainda tem conferido poucas explicaçôes para as conexóes entre os diferentes fóruns de produção de ideias e ao processo de tradução que pode haver diretamente de um fórum para outro, sem a intermediação do fórum de comunidades de política pública, onde todos os mediadores relevantes encontram-se. A rede é útil nesse caso para dinamizar a circulação de atores, ideias e valores entre os fóruns de produção de ideias. Por sua vez, o conceito de arena sublinha uma dinâmica específica de crítica e contestação que, em determinados momentos, emerge no interior do fórum de comunidades de política pública. A configuração de arena assume, portanto, um sentido muito próximo àquele de momento crítico sublinhado por Boltanski (2009), mas aplicado especificamente à dinâmica deste fórum.

Uma segunda questão analítica diz respeito à formação do referencial central nos fóruns de produção de ideias. Afinal, o que faz com que uma ideia seja prevalecente dentro de um fórum de produção de ideias? $\mathrm{O}$ foco da abordagem cognitiva volta-se fundamentalmente aos diferenciais de recurso e 
poder entre os atores. Uma representação impóe-se face às demais e conforma o referencial central da política pública porque os atores (ou coalizão de atores) que a sustentam possuem maior acesso a recursos materiais e discursivos. Sem negar a importância desse diferencial, a economia das convençóes acrescenta outro argumento: em que pese à importância dos recursos mobilizados para fazer prevalecer uma representaçáo, ela somente pode estabilizar-se se for considerada legítima pelo conjunto dos atores que participam do fórum. Essa legitimidade depende de sua inscrição em um princípio de justiça.

Finalmente, aqui reside uma contribuição fundamental para pensar a lógica dos "compromissos", termo invocado pelas duas abordagens. Na abordagem cognitiva, um compromisso sugere um acordo no curso de um processo de trocas políticas entre atores sociais com interesses e representaçôes dissonantes. Esse compromisso é a peça angular para a estabilização de normas e regras e, portanto, para a institucionalização das ideias em políticas públicas. No entanto, essa abordagem pouco diz sobre as condiçóes para que esse compromisso seja formado, exceto que ele envolve trocas políticas entre os fóruns de produção de ideias e o fórum de comunidades de política pública, em que os atores, para fazer prevalecer determinada ideia, também precisam ceder face aos interesses dos demais.

De outro modo, para a economia das convençóes, compromissos são composiçóes específicas que emergem do encontro de diferentes ordens de grandeza valorativas. Trata-se de uma chave de leitura que permite interpretar a formação de arranjos convencionais híbridos, nos quais valores, interesses e atores aparentemente irreconciliáveis são dispostos de maneira relativamente ordenada. Dois tipos de compromissos podem ser distinguidos. Primeiro, uma espécie de "compromisso proibitivo" que designa um tipo de composição entre diferentes ordens de grandeza que procura suspender as controvérsias sem resolvê-las. Os atores buscam um acordo que lhes permita evitar os objetos que postulam diferença (determinados artigos de uma lei ou condiçóes para acesso a recursos público). Nesse caso, contudo, não se trata exatamente de um diálogo entre percepçôes heteróclitas, mas da suspensão temporária do elemento de conflito.

O segundo tipo de compromisso diz respeito à construção de um arranjo em que o objeto se referencia a um novo princípio comum até então náo especificado. Nesse caso, "o compromisso sugere a eventualidade de um princípio 
capaz de tornar compatível julgamentos que se apoiam em objetos provenientes de mundos diferentes" (BOLTANSKI; THËVENOT, 1991, p. 338). A construção de um novo programa ou política pública somente é possível na medida em que concilie, por exemplo, geração de renda (cité mercantil) e conservação dos recursos naturais (cité ecológica). Caso a política não esteja em conformidade com ambos os valores, desencadeia-se um movimento de crítica que pode levar à sua reformulação ou extinção.

Contudo, uma vez que esse tipo de "compromisso constitutivo" não se vincula a nenhum valor específico, ele é mais facilmente passível de denunciação. Para que ele se estabilize é necessário "dotá-lo de uma identidade própria, de modo que sua forma não seja mais reconhecível se substraírmos dele um ou outro dos elementos de origem diferentes dos quais ele se constituiu" (BOLTANSKI; THËVENOT, 1991, p. 339). Seja como for, esse tipo de compromisso é fundamental para compor uma dinâmica de formação de "projetos" (BOLTANSKI; CHIAPELLO, 1999), os quais emergem como uma composiçáo específica unindo atores, interesses e valores diferentes em torno de um objetivo comum. O projeto unifica os atores dentro dos fóruns e confere maior capacidade para estes liderarem a construção dos referenciais hegemônicos que nortearão a política.

\section{Um modelo analítico para a política de desenvolvimento territorial: apontamentos para uma agenda de pesquisa}

A partir dos elementos teóricos acima elencados, esta seção finaliza o artigo discutindo a construção de um modelo para análise da política de desenvolvimento territorial no Brasil. A escolha desta política deriva tanto das características inerentes à mesma - as quais fazem dela um dos principais exemplos do novo formato intersetorial e descentralizado de ação pública -, quanto do acúmulo empírico proveniente de pesquisas que estão sendo conduzidas pelos autores em diferentes territórios rurais. Neste artigo dá-se preferência a uma análise integrada do modelo analítico que orienta uma agenda de pesquisa voltada não apenas para a política territorial, mas para um leque mais amplo de políticas públicas, apontando para elementos que ainda deverão ser cotejados à luz dos estudos de caso.

Dentre o conjunto de mudanças que o Brasil experimenta no modo de condução das políticas públicas, pode-se destacar que, cada vez mais, essas 
são o resultado de um processo complexo, fragmentado e policêntrico de ação pública, envolvendo uma ampla pluralidade de atores (GRISA, 2012; MASSARDIER, 2011). Este é o caso do processo de implementação das políticas de desenvolvimento territorial, particularmente do Programa Nacional de Desenvolvimento Sustentável dos Territórios Rurais (PRONAT) e do Programa Territórios da Cidadania (PTC), os quais representam as principais experiências brasileiras de ação pública sustentadas por um enfoque territorial de desenvolvimento.

Criado em 2003, o PRONAT tem sua origem relacionada às limitaçóes do PRONAF Infraestrutura como catalisador de estratégias de desenvolvimento dos espaços rurais, uma vez que este se restringia aos recortes administrativos municipais. Direcionado a agricultores familiares, povos e comunidades tradicionais, o PRONAT incita esses atores a estruturar projetos com enfoque territorial. Coordenado pelo Ministério do Desenvolvimento Agrário, o programa visa à elaboração de projetos coletivos a partir da mobilização e da formação de acordos entre atores locais situados em diferentes fóruns. Além da construção de compromissos entre distintas representaçôes do território e do processo de desenvolvimento, os projetos pautam-se pela formaçáo de novas institucionalidades e espaços públicos, os quais devem promover a participação cidadã (colegiados territoriais, regras de participação dos representantes da sociedade civil e atores governamentais, regimento interno dos colegiados, normas para o acesso aos recursos etc.).

Por sua vez, o PTC foi criado em 2008 como um desdobramento da experiência do PRONAT. O Programa articula um amplo conjunto de políticas públicas, articulando e concentrando açôes de 22 ministérios nos 120 Territórios da Cidadania distribuídos entre as diferentes regióes brasileiras. Trata-se de um "dispositivo objetivando a concentração e articulação de políticas públicas setoriais em determinados recortes territoriais" (BONNAL; KATO, 2011, p. 71). Mesmo apresentando uma dinâmica mais top-down que seu predecessor, o PTC organiza-se a partir de institucionalidades similares àquelas do PRONAT, exigindo, contudo, um exercício mais evidente de multidimensionalidade e intersetorialidade. Isso é particularmente evidente na ampliaçáo dos espaços de negociação, que passam a abarcar outros fóruns de produção de ideias presentes nas instâncias territoriais (BONNAL; KATO, 2011). 
A política de desenvolvimento territorial sugere a emergência de uma nova forma de governança condizente com a necessidade de ampliaçáo da interlocução entre atores de diferentes fóruns de produção e institucionalização de ideias (LEITE et al., 2010; FAVARETO, 2010; ARAÚJO, 2010; DELGADO; LEITE, 2011). O modelo de governança pressuposto é expressão paradigmática do modo como as açóes públicas passam a integrar e corresponsabilizar Estado e sociedade civil na gestão dos problemas públicos, envolvendo três aspectos principais: a formação e estabilização de redes heterogêneas de atores sociais (gestores, agricultores, técnicos, pesquisadores, prefeitos, vereadores, pequenos empresários etc.); a constituição de espaços públicos onde esses atores confrontam ideias e valores com vistas a formar novos compromissos (sobretudo nos Colegiados Territoriais); uma nova institucionalidade que regula as formas emergentes de relaçóes políticas (normas para transferência de recursos públicos aos territórios; recomendação de paridade entre governo e sociedade civil nos colegiados territoriais).

Os inúmeros estudos realizados sobre a política territorial no Brasil (MIRANDA; TIBÚRCIO, 2011; PERICO, 2009; BONNAL; MALUF, 2009; FAVARETO, 2010; ARAÚJO, 2010; DELGADO; LEITE, 2011) permitem propor uma síntese preliminar correspondente ao formato de ação pública encontrado nos territórios, ainda que inúmeras variaçóes apresentem-se em cada contexto específico (organização das redes; número e composição dos fóruns de produção de ideias; participação e a atuação diferenciada entre esses fóruns; mecanismos de interação entre os mesmos etc.). Representada pelo modelo proposto na Fig. 2, essa síntese sugere a existência de, pelo menos, cinco fóruns principais envolvidos no processo de produção de ideias: a) Fórum da Comunicação Política, formado pelos representantes dos poderes públicos municipais, estaduais e federal (prefeitos, vereadores, secretários etc.); b) Fórum da Agroecologia, formado por representantes de movimentos e entidades que participam da discussão e propóem novos modelos de agricultura de base ecológica; c) Fórum da Agricultura Familiar, composto pelos membros dos sindicatos e movimentos representativos dos distintos segmentos que compóem essa categoria social; d) Fórum da Segurança Alimentar, conformado por organizaçóes partícipes dos debates sobre os temas da fome e segurança alimentar e nutricional; e) Fórum Científico, formado por pesquisadores e professores que contribuem à formulação das políticas territoriais. A presença, o número, os limites e a composição destes fóruns variam de um território para o outro, assim como novos fóruns podem surgir aglutinando outros atores. 


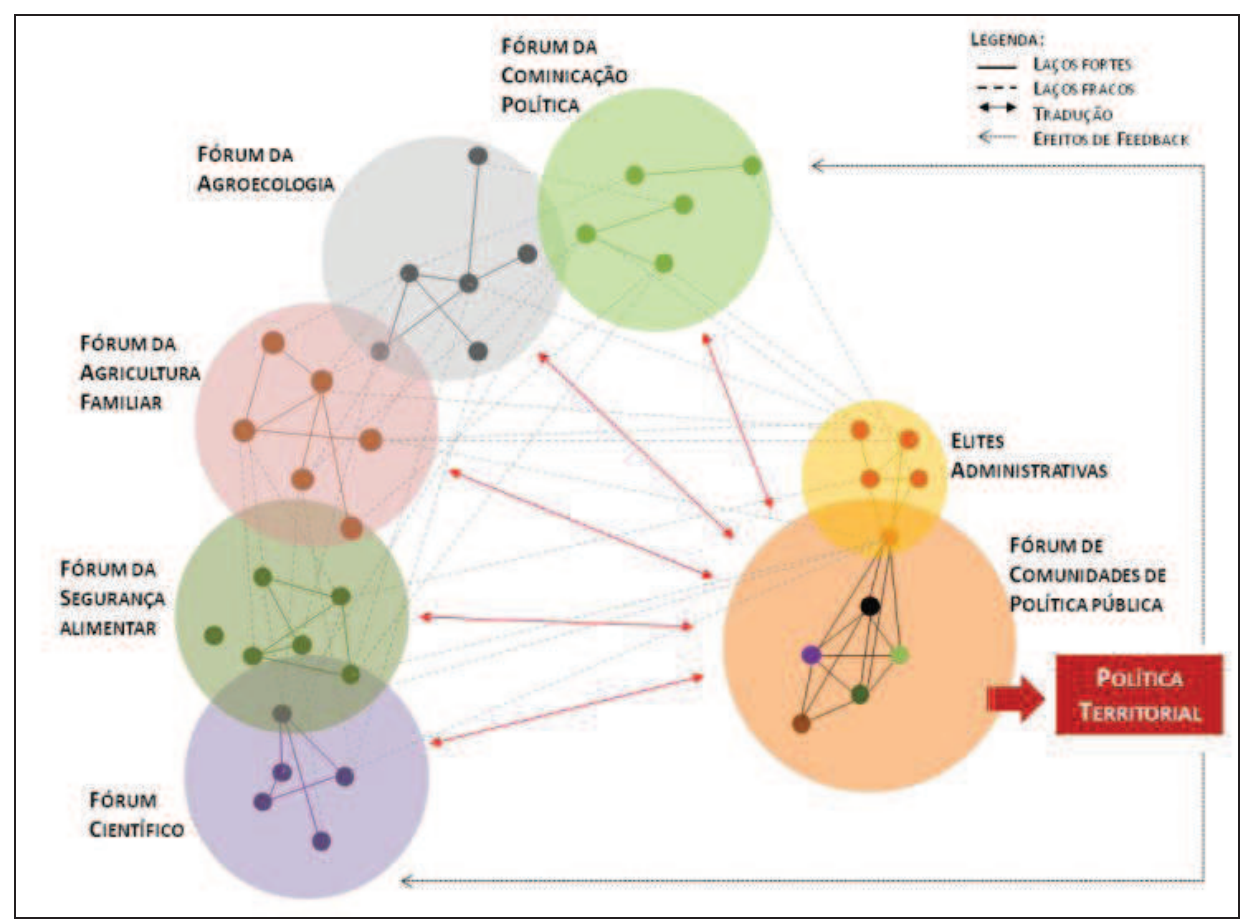

Figura 2 - Um modelo de ação pública na política de desenvolvimento territorial.

De modo geral, nota-se uma participação preponderante dos representantes do fórum da agricultura familiar e da comunicaçáo política nas discussóes territoriais, o que confere um viés rural e agrícola aos projetos de desenvolvimento (TECCHIO, 2012; BONNAL, DELGADO, CAZELLA, 2011; DELGADO E LEITE, 2011). Em várias situaçôes, isso é decorrência de constrangimentos institucionais que criam obstáculos à expansão da rede social, limitando a participaçáo de atores que poderiam desestabilizar os compromissos já constituídos no interior dos fóruns. Com isso, ao mesmo tempo que se garante estabilidade para a rede social, coloca-se em xeque a participaçáo efetiva de novos atores e, mesmo após a criação do PTC, a estrutura de governança é muito próxima àquela encontrada no PRONAT, limitando o número de fóruns e perpetuando o viés agrícola das estratégias de desenvolvimento (BRASIL, 2010). É verdade que, em alguns territórios, a emergência do PTC provocou mudanças na gestáo social dos territórios e proporcionou maior visibilidade e participação a atores outrora "invisíveis", como os indígenas, quilombolas, mulheres e jovens. Todavia, a multidimensionalidade e a articulação e institucionalização de ideias setoriais constituem ainda desafios importantes. 
No que tange à construção de uma agenda de pesquisa sobre a política territorial, uma análise dessas estruturas de governança conectada à dinâmica dos territórios deve atentar a um conjunto de questôes basilares à compreensão das interfaces entre atores e instituiçóes. $O$ foco volta-se à evolução temporal dos elementos constituintes da ação pública: Quais atores ou fóruns de produção de ideias participam da construção da política territorial? Como eles interagem? Quais ideias e valores são prevalecentes no interior desses fóruns? Como essas ideias e valores evoluíram ao longo do tempo? Como os fóruns dialogam entre si? Quais atores capitaneiam os processos de tradução existentes entre os fóruns? Quem são os porta-vozes que participam do fórum de comunidades de políticas públicas? Como esses mediadores traduzem as ideias entre os fóruns de produção de ideias e o fórum de comunidades de política pública? Qual institucionalidade (normas, regras, convençôes, códigos) regula o funcionamento desses diferentes fóruns de produção de ideias? Quais compromissos são formados entre os atores? Quais ideias são institucionalizadas e tornam-se instrumentos de política territorial? Por que essas ideias lograram êxito ao passo que outras foram excluídas? Analisadas desde uma perspectiva histórica, essas questôes podem constituir uma espécie de chave analítica para "compreender" e "avaliar" as mudanças na ação pública em nível territorial.

Tal qual empregada neste artigo, a noção de "fórum" identifica constrangimentos cognitivos e normativos às redes sociais e, portanto, à movimentação dos atores. Cada fórum define uma composição mais ou menos estável de regras e valores institucionalizados que regulam as interaçóes, definem as posições relevantes e excluem comportamentos desviantes. Um fórum constitui uma gramática estruturando a ação dos atores. No entanto, respeitando as regras inerentes a cada fórum, em momentos distintos um ator pode estar presente ou circular em diferentes fóruns de produção de ideias (a noção convencionalista de "racionalidade situada"), tornando-se responsável por um processo de tradução de ideias e valores. No caso dos territórios, é recorrente um agricultor, como representante de sindicato ou movimento social, circular em dois ou mais fóruns de produção de ideias (agricultura familiar, agroecologia, segurança alimentar), mas respeitando as regras e os valores que regem a dinâmica e organização de cada um deles. Do mesmo modo, ele pode tornar-se parte do fórum da comunicação política (elegendo-se prefeito ou vereador) ou, ainda, ingressar às elites administrativas, ratificando a crescente permeabilidade entre governo e movimentos sociais (DAGNINO, 2002). 
Um ator circulando entre vários fóruns de produção de ideias carrega consigo representaçôes sobre o modo como as políticas públicas devem ser operadas. No entanto, como destaca a economia das convençóes, essas ideias são necessariamente objeto de interpretação em contextos sociais diferenciados (BATIFOULIER; LARQUIER, 2001). Quando transportadas para o interior de diferentes fóruns de produção de ideias, as representaçóes são reinterpretadas, traduzidas para um espaço diferente daquele no qual elas foram originalmente produzidas. Esse é o caso, por exemplo, quando um o agricultor dirigente sindical adentra a esfera governamental. Suas ideias sobre a agricultura são expressas e ressignificadas no interior de um fórum regido por novos princípios normativos. As ideias são reinterpretadas e podem dar subsídio a projetos diferentes daqueles que originalmente sustentavam.

A identificação das redes - dos laços fracos e fortes ${ }^{14}$ - e da posição e movimentaçáo dos atores no interior e entre diferentes fóruns, permite a análise dos processos de troca que levam um ator a constituir-se como porta-voz. Isso também possibilita compreender a atuação diferenciada dos fóruns de produção de ideias no fórum de comunidades de política públicas, identificando distintas relaçóes de poder no processo de institucionalização da política e definiçáo dos projetos apoiados. Ademais, é importante notar que a presença dos atores nos fóruns não se constitui necessariamente em uma participação ativa na definição das políticas. Alguns atores podem estar completamente isolados (buracos estruturais) ou com relaçóes muito restritas para se tornarem porta-vozes das ideias produzidas nos fóruns. Uma abordagem histórica que identifique as mudanças ao longo do tempo permite identificar a alteração nos mediadores. A emergência de novas ideias e valores conecta-se, assim, às lutas por reconhecimento e legitimaçáo e ao empoderamento de novos atores que podem substituir os antigos porta-vozes (no caso do Fórum da Agricultura Familiar, por exemplo, vários territórios revelam uma ascensão de novos movimentos sociais e sindicais e passam a disputar a representação por ideias hegemônicas).

14 A distinção entre laços fracos e fortes segue a definição de Granovetter (1973). Enquanto os laços fortes constituem-se de interações entre atores com vínculos sociais recorrentes e, portanto, com valores e ideias mais próximos, laços fracos referem-se a interações esporádicas através das quais pode ser facilitada a circulação de informações não redundantes dentro da rede, isto é, ideias relativamente inéditas provenientes de outros fóruns capazes de catalisar processos de mudança na política pública. 
No modelo analítico proposto acima (Fig. 2), ênfase especial é conferida ao lugar das Elites Administrativas no processo de formulação das políticas. Trata-se de um espaço específico conformado pela burocracia estatal (gestores da política territorial em diferentes níveis de governo) que se reproduz de maneira mais ou menos duradoura, evidenciando a força das instituiçóes que regulam o modo de operacionalização das políticas (eg. as normas para transferência e aplicação de recursos, as modalidades de empenho, as exigibilidades relacionadas à responsabilidade fiscal). Enquanto os fóruns de produção de ideias possuem maior rotatividade dos seus porta-vozes, as Elites Administrativas tendem a se reproduzir no interior do fórum de comunidades de política pública. A título de exemplo, enquanto a mudança de governadores e prefeitos altera a composição do Fórum da Comunicação Política a cada quatro anos, os gestores da política territorial (e das políticas afins implementadas nos territórios) podem reproduzir-se em seus cargos e, junto com eles, determinadas ideias e valores sobre a construção das políticas públicas. Obviamente, isso não lhes confere uma posição intocável e as próprias representaçôes oriundas dos gestores são alteradas ao longo do tempo.

Finalmente, cabe destacar os "efeitos de feedback" da política pública. A partir do momento em que ideias e valores são institucionalizados e passam a operar através de diferentes instrumentos de política (normas, manuais, regulamentos, regimentos, planos), é necessário considerar como esses instrumentos condicionam o comportamento dos atores e a conformaçáo das redes e fóruns. São mecanismos de path dependence da política pública que definem um espaço de manobra relativamente limitado para a governança territorial. Por outro lado, trata-se igualmente do modo como as políticas públicas podem intervir sobre o funcionamento das redes e fóruns alterando o poder dos atores e, consequemente, interferindo sobre as lutas por reconhecimento. Em muitos casos, os instrumentos da política pública conseguem favorecer o enfraquecimento de formas tradicionais de dominaçáo perpetuadas nos territórios para promover o empoderamento de atores antes subordinados e invisíveis perante o Estado.

\section{Referências}

AMABLE, B.; PALOMBARINI, S. L'économie politique n'est pas une science morale. Paris: Raisons d'Agir, 2005. 
ARAÚJO, T.B. (Coord). Políticas de desenvolvimento territorial rural no Brasil: avanços e desafios. Brasília: IICA, 2010.

BATIFOULIER, P. (Dir.) Théorie des conventions. Paris: Economica, 2001.

BATIFOULlIER, P. ; GADREAU, M. Régulation et coordination du système de santé. Des institutions invisibles à la politique économique. In: EYMARD-DUVERNAY, F. (Org.). L'économie des conventions: méthodes et résultats. Paris: La Découverte, 2006.

BATIFOULIER, P.; LARQUIER, G. De la convention et de ses usages. In: BATIFOULIER, P. (Dir.) Théorie des conventions. Paris: Economica, 2001. p. 09-31.

BECKERT, J. The great transformation of embeddedness: Karl Polanyi and the New Economic Sociology. MPIfG Discussion Paper, n. 7, 2007.

BESSIS, F. Sur quelques critiques récurrentes de l'Économie des Conventions. Nanterre, Economix - Université Paris X Nanterre, Document de Travail, n.7, 2007.

BESSY, C.; FAVEREAU, O. Institutions et économie des conventions. Cahiers d'Économie Politique, v. 44, n.1, p.119-164, 2003.

BIGGART, N.; BEAMISH, T.D. The economic sociology of conventions: habit, custom, practice, and routine in market order. Annual Review of Sociology, v. 29, p. 443-464, 2003.

BOLTANSKI, L. De la critique: précis de la sociologie de l'émancipation. Paris: Gallimard, 2009. Institutions et critique sociale: une approche pragmatique de la domination. Tracés Revue de Sciences Humaines, Lyon, n. 8, p. 17-43, 2008.

. Nécessité et justification. Revue Économique, Paris, v. 53, n. 2, p. 275-89, 2002.

.; CHIAPELLO, E. Le nouvel esprit du capitalismo. Paris: Gallimard, 1999.

.; THEVENOT, L. De la justification. Paris: Gallimard, 1991.

BONNAL, P.; MALUF, R. Políticas de desenvolvimento territorial e multifuncionalidade da agricultura familiar no Brasil. Política \& Sociedade, Florianópolis, v. 8, n. 14, p. 211-250, 2009.

.; DElGado, N. G.; CAZEllA, A. A. Subsídios metodológicos ao estudo do desenvolvimento territorial rural. In: DELGADO, N.; LEITE, S. (Org.). Políticas públicas, atores sociais e desenvolvimento territorial no Brasil. Brasília: IICA, 2011. p. 35-60.

.; KATO, K. O processo contemporâneo de territorializaçáo de políticas e açôes públicas no meio rural brasileiro. In: DELGADO, N.; LEITE, S. (Org.). Políticas públicas, atores sociais e desenvolvimento territorial no Brasil. Brasília: IICA, 2011. p. 61-88. 
Ideias e valores: a análise da ação pública a partir das interfaces entre a abordagem cognitiva e a economia das convenções | Paulo André Niederle - Catia Grisa

BOYER, R. L'économie des conventions 15 ans après: un point de vue à partir de la théorie de la régulation. In: EYMARD-DUVERNAY, F. (Org.). L'économie des conventions: méthodes et résultats. Tome I - Débats. Paris: La Découverte, 2006. p.45-66.

BRASIL. Ministério do Desenvolvimento Agrário. Secretaria de Desenvolvimento Territorial. Colegiados territoriais: guia para a organização social dos territórios. Brasília: MDA, 2010.

BURT, R. S. Structural holes: the social structures of competition. England: Harvard University Press, 1992.

CAILLÉ, A. Remarques sur l'économie des conventions. In: EYMARD-DUVERNAY, F. (Org.). L'économie des conventions: méthodes et résultats. Tome I - Débats. Paris: La Découverte, 2006. p. 93-102.

CALLON, M. Dos estudos de laboratório aos estudos de coletivos heterogêneos, passando pelos gerenciamentos econômicos. Sociologias, Porto Alegre, v.10, n.19, p.302-321, 2008.

CORCUFF, P. As novas sociologias: construçôes da realidade social. Bauru (SP): Edusc, 2001.

DAGNINO, E. Sociedade civil, espaços públicos e a construção democrática no Brasil: limites e possibilidades. In: DAGNINO, E. (Org.). Sociedade civil e espaços públicos no Brasil. São Paulo: Paz e Terra, 2002. p. 279-302.

DELGADO, N. G.; LEITE, S. P. Políticas de desenvolvimento territorial no meio rural brasileiro: novas institucionalidades e protagonismo dos atores. Dados, v. 54, n. 2, p. 431-473, 2011.

DELGADO, N. G.; LEITE, S. P. Gestão social e novas institucionalidades no âmbito da política de desenvolvimento territorial. In: DELGADO, N.; LEITE, S. (Org.). Políticas públicas, atores sociais e desenvolvimento territorial no Brasil. Brasília: IICA, 2011, p. 89-130.

DODIER, N. Agir dans plusieurs mondes. Critiques, Paris, v. 47, n. 529-530, p. 428-458, 1991. DUMÉNIL, G.; LÉVY, D. The Crisis of Neoliberalism. Harvard: Harvard University Press, 2011. DUPUY, J.P. Convention et Common Knowledge. Revue Économique, Paris, v. 40, n. 2, p. 361 370, 1989.

EYMARD-DUVERNAY, F. L'économie des conventions entre économie et sociologie. In: STEINER, P.; VATIN, F. (Org.) Traité de sociologie économique. Paris: Quadrige-PUF, 2009, p.131-164.

Approches institutionnalistes de l'État Social. Revue Française de Socio-Économie, Paris, v. 1, n. 1, p. 89-105, 2008.

. Conventions de qualité et formes de coordination. Revue Économique, Paris, v. 40, n. 2, p. 329-59, 1989. 
et al. Valeurs, coordination et rationalité : trois thèmes mis en relations par l'économie des conventions. In: EYMARD-DUVERNAY, F. (Org.) L'économie des conventions: méthodes et résultats. Tome I - Débats. Paris: La Découverte, 2006, p. 23-44.

. et al. Pluralist integration in the economic and social sciences: the economy of conventions.

Post-autistic Economics Review, Paris, n.34, article 2, p.22-40, October 2005.

FAVARETO, A. Tendências contemporâneas dos estudos e políticas sobre o desenvolvimento territorial. In: ARAÚJO, T. B. (Coord). Políticas de desenvolvimento territorial rural no Brasil: avanços e desafios. Brasília: IICA, 2010, p. 15-46.

FAVEREAU, O. Marchés internes, marchés externes. Revue Économique, Paris, v. 40, n. 2, p. 273-328, 1989.

FAVEREAU, O.; BIENCOURT, B.; EYMARD-DUVERNAY, F. Where do markets come from? From (quality) conventions! In: FAVEREAU, O.; LAZEGA, E. (Ed.). Conventions and structures in economic organizations: markets, networks and hierarchies. Cheltenham: Edward Elgar, 2002, p. 213-252.

FAURE, A.; POLLET, G.; WARIN, P. La construction du sens dans les politiques publiques: débats autour de la notion de référentiel. Paris: L'Harmattan, 1995.

FLEXOR, G.; LEITE, S. Análise das políticas públicas: breves consideraçôes teóricometodológicas. In: LIMA, E. F; DELGADO, N.; MOREIRA, R. (Org.) Mundo Rural IV: configuraçấo rural-urbanas. Rio de Janeiro (RJ): Mauad, 2007.

FOUILLEUX, È. Analisar a mudança: políticas públicas e debates num sistema em diferentes níveis de governança. Estudos Sociedade e Agricultura, Rio de Janeiro, v. 19, n. 1, p. 88-125, 2011.

. Acteurs et concurrences dans la fabrication des référentiels internationaux. Le FAO et les normes de politique agricole. In: SCHEMEIL, Y.; EBERWEIN, W-D. (Dir.). Normer le monde. Paris: L'Harmattan, 2009, p. 153-175.

. La politique agricole commune et ses réformes: une politique à l'épreuve de la globalisation. Paris: L’Harmattan, 2003.

Entre production et institutionnalisation des idées: la réforme de la politique agricole commune. Revue Française de Science Politique, v. 50, n. 2, p. 277-306, 2000.

GOHN, M. G. Empoderamento e participação da comunidade em políticas sociais. Saúde e Sociedade, São Paulo, v. 13, n. 2, p. 20-31, 2004.

GRANOVETTER, M. Economic action and social structure: the problem of embeddedness. American Journal of Sociology, v. 91, n. 3, p. 481-510, 1985. 
Ideias e valores: a análise da ação pública a partir das interfaces entre a abordagem cognitiva e a economia das convenções | Paulo André Niederle - Catia Grisa

GRANOVETTER, M. The strength of weak ties. American Journal of Sociology, v. 78, n. 6, p. 1360-1380, 1973.

GRISA, C. Políticas públicas para a agricultura familiar no Brasil: produção e institucionalizaçáo das ideias. Rio de Janeiro. Tese (Doutorado de Ciências Sociais em Desenvolvimento, Agricultura e Sociedade). Universidade Federal Rural do Rio de Janeiro, 2012.

GRISA, C. As ideias na produção de políticas públicas: contribuiçóes da abordagem cognitiva. In: BONNAL, P.; LEITE, S. Análise comparada de políticas agrícolas. Rio de Janeiro: Mauad X, 2011, p. 93-138.

HALL, P. A. The role of interests, institutions, and ideas in the comparative political economy of industrialized nations. In: LICHBACK, M.; ZUCKERMAN, A. (Org.). Comparative politics: rationality, culture and structure. Nova York, Cambridge University Press, 1997, p. 174-207.

HASSENTEUFEL, P. Sociologie politique: l'action publique. Paris: Armand Colin, 2008.

HASSENTEUFEL, P. Do policy networks matter? Lifting descriptif et analise de l'État en interaction. In : LE GALES, P. ; THATCHER, M. (Dir.). Les réseaux de politique publique: débat autour des policy networks. Paris : L’Harmattan, 1995, p. 91-107.

HEMPEL, C.G.; OPPENHEIM, P. Studies in the logic of explanation. Philosophy of Science, v. 15 , n. 2 , p. $135-175,1948$.

HONNETH, A. Luta por reconhecimento: a gramática moral dos conflitos sociais. São Paulo: Ed. 34, 2003.

JOAS, H. Pragmatism and social theory. Chicago: University of Chicago, 1993.

JOBERT, B. Une approche dialectique des politiques publiques: l'heritage de l'État en action. Pôle Sud, Montpellier, França, n. 21, p. 43-54, nov. 2004.

Rhétorique politique, controverses scientifiques et construction des normes institutionnelles: esquisse d'un parcours de recherche. In: FAURE, A.; POLLET, G.; WARIN, P. (Org.). La construction du sens dans les politiques publiques: débats autour de la notion de référentiel. Paris: Éditions L'Harmattan, 1995, p.13-24.

Introduction: le retour du politique. In: JOBERT, B. (Org.). Le tournant neoliberal en

Europe: idées et recettes dans les pratiques gouvernementales. Paris: L'Harmattan, 1994, p.9-20.

Représentations sociales controverses et débats dans la conduite des politiques publiques.

Revue Française de Science Politique, a. 42, n. 2, p. 219-234,1992.

.; MULLER, P. L'état en action. Paris: PUF, 1987. 
LASCOUMES, P.; LE GALÈS, P. Sociologie de l'action publique. Paris: Armand Colin, 2009. LASCOUMES, P.; LE GALÈS, P. Gouverner par les instruments. Paris: Sciences Po, 2004.

LATOUR, B. Moderniser ou écologiser? À la recherche de la "séptième" cité. Ecologie politique, Paris, n.13, p.5-27, 1995.

LAZEGA, E. MOUNIER, L. Interdependent entrepreneurs and social discipline of their cooperation: a research program for structural economic sociology in a society of organizations. In: FAVEREAU, O.; LAZEGA, E. Conventions and structures in economic organizations: markets, networks and hierarchies. Cheltenham: Edward Elgar, 2002, pp.147-199.

LAZEGA, E.; FAVEREAU, O. Introduction. In: FAVEREAU, O.; LAZEGA, E. Conventions and structures in economic organizations: markets, networks and hierarchies. Cheltenham: Edward Elgar, 2002, p.1-28.

LEITE, S.P. et al. Políticas públicas, desenvolvimento territorial e atores sociais no meio rural. In: DELGADO, N.G. (Coord.). Brasil Rural em Debate. Brasília: CONDRAF/MDA, 2010, p. 319-360.

LEWIS, D. Convention: a philosophical study. Cambridge: Harvard University Press, 1969.

LIVIAN, Y-F.; HERREROS, G. L'apport des économies de la grandeur: une nouvelle grille d'analyse des organisations? Revue Française de Gestion, Cachan, France, v. 101, n.3, p. 43-59, 1994.

MAHONEY, J. Path-dependent explanations of regime change: Central America in comparative perspective. Studies in Comparative International Development, Providence, Rhode Island, v. 6 , n. 1, 2001.

MARQUES, E. Estado e redes sociais: permeabilidade e coesão nas políticas urbanas no Rio de Janeiro. São Paulo: Revan/FAPESP, 2000.

MASSARDIER, G. Cognição, políticas e açôes públicas: entre coerência, fragmentação e aprendizados. In: BONNAL, P.; LEITE, S.P. (Org.). Análise comparada de políticas agrícolas: uma agenda em transformaçáo. Rio de Janeiro: Mauad X, 2011, p. 69-91.

MASSARDIER, G. Politiques et actions publiques. 2. ed. Paris: Armand Colins, 2008.

MELLO, M. A. Estado, governo e políticas públicas. In: MICELI, S. (Org.). O que ler na ciência social brasileira (1970-1995), v.3, São Paulo/Brasília: ANPOCS/ CAPES, 1999.

MIRANDA, C.; TIBÚRCIO, B. (Coord.) Políticas de Desenvolvimento Rural Territorial: desafios para a construção de um marco jurídico normativo. Brasília: IICA, 2011.

MULLER, P. Les politiques publiques. 7. ed. Paris: PUF, 2008. 
Ideias e valores: a análise da ação pública a partir das interfaces entre a abordagem cognitiva e a economia das convenções | Paulo André Niederle - Catia Grisa

MULLER, P. Esquisse d'une théorie du changement dans l'action publique: structures, acteurs e cadres cognitifs. Revue Française de Sciense Politique. v. 55, n. 1, p. 155-187, 2005.

MULLER, P. L'analyse cognitive des politiques publiques: vers une sociologie politique de l'action publique. Revue Française de Sciense Politique. v. 50, n. 2, p. 189-207, 2000.

MULLER, P.; SUREL, Y. A análise de políticas públicas. 2. ed. Pelotas: Educat, 2004.

NEE, V.; INGRAM, P. Embeddedness and beyond: institutions, exchange, and social structure. In: BRINTON, M. C.; NEE, V. The new institutionalism in sociology. New York: Russel Sage Foudation, 1998, p. 19-45.

NIRDERLE, P. A. Compromissos para a qualidade: projetos de indicaçáo geográfica para vinhos no Brasil e na França. Rio de Janeiro. Tese (Doutorado de Ciências Sociais em Desenvolvimento, Agricultura e Sociedade). Universidade Federal Rural do Rio de Janeiro, 2011.

OFFE, C. A atual transição histórica e algumas opçóes básicas para as instituições da sociedade. In: BRESSER PEREIRA, L. C.; WILHEIM, J.; SOLA, L. (Org.). Sociedade e Estado em transformaçáo. São Paulo/Brasília: Editora Unesp/Enap, 1999, p. 119-145.

ORLÉAN, A. Pour une approche cognitive des conventions économiques. Revue Économique, Paris, v. 40, n. 2, p. 241-272, 1989.

PALIER, B.; SUREL, Y. Les “trois I" et l'analyse de l'État en action. Revue Française de Sciense Politique, v. 55, n. 1, p. 07-32, 2005.

PERICO, R. E. Identidade e território no Brasil. Brasília: IICA, 2009.

PERNIN, J. L. Essai sur les régimes de combinaisons de cités et la dynamique des mondes. Cahiers du GRES, Bordeaux/Toulose, France, n. 4, p. 1-43, 2005.

PIERSON, P. Public Policies as Institutions. In: GALVIN, D.; SHAPIRO, I; SKOWRONEK, S. (Ed.). Rethinking Political Institutions: The Art of the State. New York: New York City University Press, 2006, p. 114-134.

POLLET, G. Analyse des politiques publiques et perspectives théoriques. In: FAURE, A.; POLLET, G.; WARIN, P. (Dir.). La construction du sens dans les politiques publiques: débats autour de la notion de référentiel. Paris: L'Harmattan, 1995, p. 25-47.

POSTEL, N.; SOBEL, R. Quelle théorie hétérodoxe de l'acteur économique. In: EYMARDDUVERNAY, F. (Org.). L'économie des conventions: méthodes et résultats. Tome I - Débats. Paris: La Découverte, 2006, p.131-150.

RAMAUX, C. Les assymetries et les conflits sont-ils solubles dans la cognition? Une lecture critique de l'Économies de la grandeur. Économies et Société, Paris, v. 2, n. 9, p. 71-84, 1996. 
RHODES, R. A. W. Policy Network Analysis. In: MORAN, M.; REIN, M.; GOODIN, R. (Ed.) The Oxford Hanbook of Public Policy. Oxford: Oxford University Press, 2006, p. 425-447.

ROMANO, J. O. Política nas políticas: um olhar sobre a agricultura brasileira. Rio de Janeiro (RJ): Mauad X/Edur-UFRRJ, 2009.

SABATIER, P.; SCHLAGER, E. Les approches cognitives des politiques publiques: perspectives américaines. Revue Française de Science Politique, v. 50, n. 2, p. 209-234, 2000.

SALAIS, R. L'analyse économique des conventions du travail. Revue Économique, Paris, n. 40, v. 2, p. 199-240, 1989.

SMYRL, M. Regulation institutionelle et dynamique du politique: vers um programme de recherche international et trans-sectoriel em politique publique. Paris: Centre d'Etude Politique de l'Europe Latine, 2006.

SOUZA, C. "Estado do campo" da pesquisa em política pública no Brasil. Revista Brasileira de Ciências Sociais, v. 18, n. 51, p. 15-20, fev. 2003.

SUREL, Y. Approches cognitives. In: BOUSSAGUET, L.; JACQUOT, S.; RAVINET, P. (Org.) Dictionnaire de politiques publiques, 2. ed. Paris: Sciences Po, 2006, p. 80-88.

SUREL, Y. L'intégration européenne vue par l'approche cognitive et normative des politiques publiques. Revue Française de Science Politique. v. 50, n. 2, p. 235-254, 2000.

SUREL, Y. Idées, intérêts, institutions dans l'analyse des politiques publiques. Pouvoirs, Paris, n. 87, p.161-178, 1998.

SUREL, Y. Les politiques publiques comme paradigmes. In: FAURE, A.; POLLET, G.; WARIN, P. La construction du sens dans les politiques publiques: débats autour de la notion de référentiel. Paris: Éditions L"Harmattan, 1995, p.125-151.

THÈVENOT, L. Pragmatic regimes governing the engagement with the world. In: SCHATZKI, T.; KNORR CETINA, K.; VON SAVIGNY, E. (Ed.). The practice turn in contemporary theory. London e New York: Routledge, 2001, p. 56-73.

VANDENBERGUE, F. Construçáo e crítica na nova sociologia francesa. Sociedade e Estado, Brasília, DF., v. 21, n. 2, p. 315-366, 2006.

VERDIER, E. Conventions et régimes d'action en matière de R\&D et d'innovation: les modalités sociétales de construction du bien commun. In : EYMARD-DUVERNAY, F. (Org.) L'économie des conventions: méthodes et résultats. Tome II. Paris: La Découverte, 2006, p. 421-437. 
Ideias e valores: a análise da ação pública a partir das interfaces entre a abordagem cognitiva e a economia das convenções | Paulo André Niederle - Catia Grisa

WHITE, H. Identity and control: how social formations emerge. 2. ed. Princeton: Princeton University Press, 2008.

ZELIZER, V. Circuits within capitalism. In: NEE, V.; SWEDBERG, R. (Org.). The economic sociology of capitalism. Cambridge: Cambridge University Press, 2003, p.289-319.

ZUKIN, S.; DiMAGGIO, P. Introduction. In: ZUKIN, S.; DiMAGGIO, P. (Org.). Structures of capital. Cambridge: Cambridge University Press, 1990, p. 1-36.

Recebido em 31/03/2012

Aprovado em 19/09/2012

\section{Ideas and values: interfaces between cognitive and conventionalist perspectives for public action analysis}

\section{Abstract}

The focus on interests, ideas and institutions defines the three main traditions in the public policy analysis. In consequence, the unity of these concepts in a single approach also delineates the principal challenge for the construction of new approaches able to consider the complexity of the public action. The paper contributes to this discussion analyzing the interfaces between cognitive and conventionalist perspectives, two theoretical French schools that have lent their analytical categories for understanding the processes of construction and institutionalization of the public policies. The convergences allow integrate cognitive and normative mechanisms in an institutional structure supporting the public policy networks. Finally, the paper exemplifies the possibilities of this theoretical interface proposing an analytical framework for the study of territorial development policies in Brazil.

Keywords: Public action. Public policy. Ideas. Values. 